\title{
Efficacy of fungicides, plant resistance activators and biological control agents against guava wilt disease caused by Nalanthamala psidii
}

\author{
Maritha H Schoeman ${ }^{1}$, Nico Labuschagne ${ }^{2}$ and Frikkie J Calitz ${ }^{3}$ \\ ${ }^{1}$ Agricultural Research Council-Institute for Tropical and Subtropical Crops, Nelspruit, South \\ Africa \\ ${ }^{2}$ Department of Microbiology and Plant Pathology, University of Pretoria, Pretoria, South Africa \\ ${ }^{3}$ ARC Biometry, 1134 Park Street, Hatfield, Pretoria, 0083, South Africa \\ Corresponding author, e-mail:maritha@arc.agric.za
}

\begin{abstract}
Guava wilt disease (GWD) caused by the fungus Nalanthamala psidii remains a major constraint to guava production in South Africa and South East Asia. In the current study, chemical and biological products as well as plant resistance activators were evaluated for control of GWD in shadehouse and glasshouse trials. In all trials, one-year-old 'TS-G2' guava plants were used. Plants were inoculated with a macerated culture suspension of a mixture of three isolates of $\boldsymbol{N}$. psidii after artificial wounding of the roots. Products were applied as a soil drench or as a full cover spray. In trial 1 plants were evaluated according to a disease severity scale. In trial 2 and 3 data were recorded as number of dead plants at the termination of the trial. None of the chemical treatments caused a significant suppression of the disease. The best control was achieved with the combination of rhizobacterial strains Bacillus cereus S7 and Paenibacillus alvei T29 resulting in $53.4 \%$ and $50 \%$ disease control in trials 2 and 3 respectively. This treatment also seems to have a plant growth enhancing effect apart from disease suppression. This is to our knowledge the first report of control of GWD by means of bacterial antagonists.
\end{abstract}

Keywords: PGPR, biocontrol agents, guava wilt, Nalanthamala psidii

\section{Introduction}

In South Africa (SA), the area devoted to guava production covered ca. 1200 ha in 2014 (Schoeman \& Labuschagne 2014). The largest production area was the Western Cape Province (547 ha), followed by the Limpopo Province (442 ha) and the Mpumalanga Province (140 ha). The area under guava production is however diminishing at a rapid rate in the Mpumalanga and Limpopo provinces due to a devastating wilting disease (Schoeman \& Labuschagne 2014).

Guava wilt, caused by Nalanthamala psidii (Sawada \& Kuros.) Schroers \& M.J. Wingf. (Schroers et al. 2005) was first reported from the Malelane area (Mpumalanga Province of South Africa), in 1981 (Grech 1985; Grech 1990). At that stage the guava industry relied solely on the Fan Retief (FR) cultivar. The disease spread rapidly throughout the guava-producing areas of the Limpopo and Mpumalanga provinces within less than 10 years.

Symptoms of guava wilt disease (GWD) include a wilting of the foliage in the upper branches, which subsequently spreads throughout the whole tree. During rapid decline, leaves tend to shrivel and die on the trees, which assume a 
scorched appearance. When decline occurs more slowly, leaves drop gradually, resulting in complete defoliation (Schoeman et al. 1997).

Infection occurs mainly through the roots (Grech, 1986). After infection of the roots the pathogen moves in the xylem. The fungus can be isolated from all woody parts of the plant showing GWD symptoms. Where sectorial infections occur the fungus can also be isolated from asymptomatic branches. Wounding enhances disease development and symptoms can develop within 3 months after artificial inoculation of roots in the field and trees can be dead within 6 months (Lim \& Manicom 2003).

GWD is also present in South-east Asia where it is caused by the same fungus as in SA (Schoeman \& Labuschagne 2014). A different wilt disease of guava caused by Fusarium oxysporum f. sp. psidii caused losses of up to $30 \%$ in India.

Apart from eradication of diseased trees, there are currently no effective control measures for GWD. In SA, various fungicides have been evaluated over several years against the pathogen, without any success (MHS unpublished data). Some products have been reported to control the various wilt pathogens in laboratory tests, but failed in vivo (Leu et al. 1979; Joubert and Frean 1993; Misra \& Pandey 1999).

In South Africa, two resistant guava rootstocks (TS-G1 and 'TS-G2') were developed by the Agricultural Research Council - Institute for Tropical and Subtropical Crops (ARC-ITSC) $\left(25^{\circ} 27^{\prime} 04.6^{\prime \prime}\right.$ S, 30 38'09.1" E) in 1995 (Schoeman 1995). These rootstocks were selected after 30000 tissue cultured guava seedlings had been screened for resistance / tolerance by exposure to a culture filtrate of the GWD fungus (Vos et al. 2000). Plant Breeders Rights were granted (Grant No. ZA 20002283) for one of the most tolerant rootstock selections 'TSG2' on 25 January 2000 after field evaluation demonstrated the yield and fruit quality of this rootstock to be commercially acceptable. In 2007 an estimated 600 ha of both TS-G1 which was never registered, and 'TS-G2', were established in the Mpumalanga and Limpopo Provinces. Currently, only ungrafted 'TS-G2' trees, derived from rooted cuttings, are being used in the industry (Schoeman 2011).

In 2009 a second outbreak of GWD was reported from several localities in South Africa, also affecting the formerly resistant 'TS-G2' cultivar. This suggests that a new virulent strain / race of $N$. psidii has evolved, placing the guava industry under threat once again. Long term measures currently undertaken to address this new threat include further in vitro screening of thousands of guava seeds using cell free filtrates derived from the newly-isolated $N$. psidii strains (Schoeman \& Labuschagne 2014). As a short term solution chemical and biological control products are being screened.

The aim of the current study was to evaluate chemical and biological products as well as plant resistance activators for control of guava wilt disease in shadehouse and glasshouse trials. 


\section{Materials and methods}

The study consisted of three trials in which one-year-old 'TS-G2' guava plants obtained from Du Roi Nursery, Letsitele, were used. The plants were $30 \mathrm{~cm}$ in height and were planted in $4 \mathrm{~L}$ capacity black plastic bags (Dimensions: $20 \mathrm{~cm}$ height and $15 \mathrm{~cm}$ diameter) containing composted pine bark medium

Pathogen inoculum was produced by growing three isolates of $N$. psidii (FR, G2 and G1) (Schoeman and Labuschagne 2014) separately on malt extract agar plates $\left(90 \mathrm{~mm}\right.$ diameter) for 10 days at $25^{\circ} \mathrm{C}$. For inoculation, three culture plates (one per isolate) were macerated together in $2 \mathrm{~L}$ of sterile water for 1 minute and $200 \mathrm{ml}$ of the resulting suspension applied per plant bag as a drench treatment.

In Trial 1 the roots of the plants were wounded directly before inoculation by thrusting a sterilised blade (width $27 \mathrm{~mm}$; thickness $0.8 \mathrm{~mm}$ ) of a knife into the root system at three locations around the stem. In Trial 2 and 3 the roots were wounded only in one location 18 hours before inoculation with the pathogen.

The experimental layout of Trial 1 was a randomized complete block design with 16 treatments randomly allocated within each of the 3 replicate blocks. An experimental unit consisted of 8 plants (i.e. a total of 24 plants per treatment). The trial was conducted in a shadehouse at ambient temperature from February to April 2012. Plants were watered with tap water 3 times per week. The treatments are listed in Table 1.

The experimental layout of Trial 2 was a randomized complete block design with 10 treatments randomly allocated within each of three replicate blocks. An experimental unit consisted of 5 plants (resulting in a total of 15 plants per treatment). The treatments are listed in Table 2. Trial 2 was conducted in a glasshouse with temperature set at $27^{\circ} \mathrm{C} \pm 2$. 
Table 1. Details of treatments evaluated for control of GWD in a shadehouse during Trial 1

\begin{tabular}{|c|c|c|c|c|}
\hline $\begin{array}{c}\text { Treatment } \\
\text { no* }\end{array}$ & Treatment & Active ingredient & Concentration & $\begin{array}{l}\text { Application method/ } \\
\text { dosage }\end{array}$ \\
\hline 1 & Bion $^{(8)}$ WG $500 \mathrm{~g} / \mathrm{kg}$ & Acibenzolar-S-methyl & $0.05 \mathrm{~g} / \mathrm{L}$ & Full cover spray \\
\hline 2 & AgriSil $^{\mathrm{IM}} \mathrm{K} 50$ & Potassium silicate $^{\mathrm{a}}$ & $0.4 \mathrm{ml} / \mathrm{L}$ & Drench $(200 \mathrm{~mL} /$ plant bag) \\
\hline 3 & Alexin & 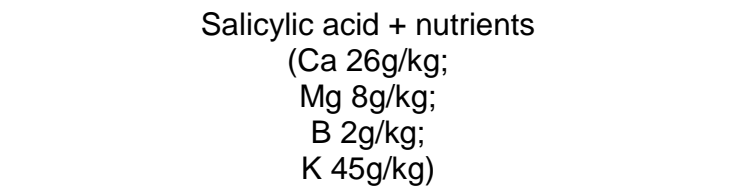 & $5 \mathrm{ml} / \mathrm{L}$ & Full cover spray \\
\hline 4 & Aliette ${ }^{(\Theta)}$ WG $800 \mathrm{~g} / \mathrm{kg}$ & Fosetyl-Al & $3.75 \mathrm{~g} / \mathrm{L}$ & Full cover spray \\
\hline 5 & Trichoderma $\left(\mathrm{Eco} \mathrm{T}^{(}\right)$ & Trichoderma harzianum ( $2 \times 10^{y}$ spores/gram) & $0.25 \mathrm{~g} / \mathrm{L}$ & Drench $(200 \mathrm{~mL} /$ plant bag) \\
\hline 6 & Trichoderma $\left(\mathrm{Eco}^{-\mathrm{T}^{(\mathrm{B})}}\right)+$ AgriSil $^{\mathrm{IM}} \mathrm{K} 50$ & $\begin{array}{c}\text { Trichoderma harzianum }\left(2 \times 10^{y} \text { spores/gram }\right)+ \\
\text { potassium silicate }\end{array}$ & $\begin{array}{c}0.25 \mathrm{~g} / \mathrm{L}+ \\
0.4 \mathrm{ml} / \mathrm{L}\end{array}$ & Drench $(200 \mathrm{~mL} /$ plant bag $)$ \\
\hline 7 & Trichoderma (Tricho Plus $\left.{ }^{(}\right)$ & Trichoderma harzianum ( $2 \times 10^{y}$ spores/gram) & $0.25 \mathrm{~g} / \mathrm{L}$ & Drench $(200 \mathrm{~mL} /$ plant bag) \\
\hline 8 & Microbial Solutions $^{\mathrm{b}}$ & $\begin{array}{c}\text { DPress }^{(B)} \text { (Bacillus sp.) + Superguard }{ }^{(B)} \text { (amino } \\
\text { phosphonate) + activator }+ \\
\text { Waterbac }{ }^{(B)} \text { (Bacillus spp. } \times 3\left(2 \times 10^{y} \mathrm{cfu}\right)\end{array}$ & $\begin{array}{c}10 \mathrm{ml}+50 \mathrm{ml}+ \\
10 \mathrm{ml}+ \\
10 \mathrm{ml} / \mathrm{L}\end{array}$ & Drench (200mL/plant bag) \\
\hline 9 & Negative control $^{\mathrm{c}}$ & - & & \\
\hline 10 & Positive control $^{d}$ & - & & \\
\hline 11 & Indar $^{(B)} 50 \mathrm{EW}$ & Fenbuconazole & $0.8 \mathrm{ml} / \mathrm{L}$ & Drench (200mL/plant bag) \\
\hline 12 & Rally ${ }^{(B)} 200 \mathrm{EW}$ & Myclobutanil & $0.15 \mathrm{ml} / \mathrm{L}$ & Drench $(200 \mathrm{~mL} /$ plant bag) \\
\hline 13 & A-team $240 \mathrm{~g} / \mathrm{L}$ & Azoxystrobin $240 \mathrm{~g}$ a.i. $/ \mathrm{L}$ + tebuconazole $240 \mathrm{~g}$ a.i./L & $0.00338 \mathrm{ml} / \mathrm{L}$ & Drench $200 \mathrm{~mL} /$ plant bag) \\
\hline 14 & Bendazid $^{(B)} 500 \mathrm{SC}$ & Carbendazim & $0.0112 \mathrm{ml} / \mathrm{L}$ & Drench (200mL/plant bag) \\
\hline 15 & Amistar ${ }^{(\theta)} 660$ SC & Azoxystrobin & $1 \mathrm{ml} / \mathrm{L}$ & Drench (200mL/plant bag) \\
\hline 16 & Nativo $^{(B)} 300$ SC & $\begin{array}{l}\text { Trifloxystrobin } 100 \mathrm{~g} \text { a.i. } / \mathrm{L} \\
+ \text { tebuconazole } 200 \mathrm{~g} \text { a.i. } / \mathrm{L}\end{array}$ & $0.009 \mathrm{ml} / \mathrm{L}$ & Drench (200mL/plant bag) \\
\hline
\end{tabular}

a Soluble potassium silicate.

${ }^{\mathrm{b}}$ Dpress ${ }^{\circledR}+$ Activator + Superguard ${ }^{\circledR}$ one week before inoculation followed by Waterbac ${ }^{\circledR}+$ activator 14 days later and repeated every two months (Microbial solutions refer to the supplier of the products)

${ }^{c}$ Negative control plants were inoculated with macerated agar only

${ }^{d}$ Positive control plants were inoculated with a mixture of GWD isolates only and received no other treatments

${ }^{*}$ Treatments 1-8 were applied one week before inoculation with the pathogen and treatments 11-16, 24 hours before inoculation. Treatment 8 consisted of a combination of four products namely DPress ${ }^{\circledR}$, Superguard ${ }^{\circledR}$, activator and Waterbac ${ }^{\circledR}$. Waterbac ${ }^{\circledR}$ plus activator was applied 14 days after the DPress ${ }^{\circledR}+$

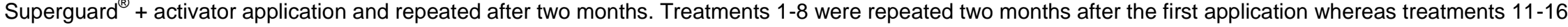
were repeated 12 days after the first application. 
Table 2. Details of treatments evaluated for control of GWD in a shade/house during Trial 2

\begin{tabular}{|c|c|c|c|c|}
\hline $\begin{array}{l}\text { Treatment } \\
\text { no* }\end{array}$ & Treatment & Active ingredient & Concentration & $\begin{array}{c}\text { Application method and } \\
\text { dosage }\end{array}$ \\
\hline 1 & Bion $\left.^{(}\right)$WG $500 \mathrm{~g} / \mathrm{kg}$ & Acibenzolar-S-methyl & $0.05 \mathrm{~g} / \mathrm{L}$ & Full cover spray \\
\hline 2 & AgriSil ${ }^{1 \mathrm{M}} \mathrm{K} 50$ & Potassium silicate ${ }^{a}$ & $0.4 \mathrm{ml} / \mathrm{L}$ & Drench $(200 \mathrm{~mL} /$ plant bag) \\
\hline 3 & Eco $T^{(B)}$ & Trichoderma harzianum ( $2 \times 10^{y}$ spores/gram) & $0.25 \mathrm{~g} / \mathrm{L}$ & Drench (200mL/plant bag) \\
\hline 4 & $\begin{array}{c}\text { Eco- }^{(\mathbb{B})}+\text { AgriSil }^{\text {IM }} \\
\mathrm{K} 50\end{array}$ & Trichoderma harzianum $\left(2 \times 10^{y}\right.$ spores/gram $)+$ & $0.25 \mathrm{~g} / \mathrm{L}+$ & Drench $(200 \mathrm{~mL} /$ plant bag) \\
\hline 5 & Microbial Solutions ${ }^{b}$ & $\begin{array}{c}\text { potassium silicate }^{\mathrm{a}} \\
\text { DPress }^{(B)} \begin{array}{c}\text { (Bacillus sp. })+ \text { Superguard }^{(B)} \text { (amino } \\
\text { phosphonate })+ \text { activator }^{(B)}\end{array} \\
\text { Waterbac }^{(B)}\left(\text { Bacillus spp. } \times 3 \text { - microbial strength } 2 \times 10^{y} \text { ) }\right.\end{array}$ & $\begin{array}{c}0.4 \mathrm{ml} / \mathrm{L} \\
10 \mathrm{ml}+50 \mathrm{ml}+ \\
10 \mathrm{ml}+ \\
10 \mathrm{ml} / \mathrm{L}\end{array}$ & Drench $(200 \mathrm{~mL} /$ plant bag) \\
\hline 6 & UP-PGPR strains ${ }^{c}$ & $\begin{array}{c}\text { Bacillus cereus strain } \mathrm{S} 7+\text { Paenibacillus alvei } \\
\text { strain T29 }\end{array}$ & $\begin{array}{l}100 \mathrm{ml}^{\mathrm{d}} \text { of strain } \mathrm{S} 7+ \\
100 \mathrm{ml}^{\mathrm{d}} \text { of strain T29 }\end{array}$ & Drench $(200 \mathrm{~mL} /$ plant bag) \\
\hline 7 & Agro-Mos ${ }^{1 \mathrm{M}}$ & Nitrogen $1.9 \mathrm{~g} / \mathrm{kg}+$ copper $40 \mathrm{~g} / \mathrm{kg}+$ brewed dried yeast & $1 \mathrm{ml} / \mathrm{L}$ & Full cover spray \\
\hline 8 & Bellis ${ }^{\mathrm{IM}}$ & Boscalid/pyraclostrobin & $0.00675 \mathrm{~g} / \mathrm{L}$ & Drench $(200 \mathrm{~mL} /$ plant bag) \\
\hline 9 & Positive control $^{e}$ & - & - & - \\
\hline 10 & Negative control $^{\dagger}$ & - & - & - \\
\hline
\end{tabular}

a Soluble potassium silicate

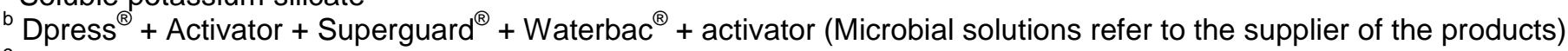

c Rhizobacterial strains from the University of Pretoria's PGPR culture collection.

d Bacterial cells in broth culture.

e Negative control plants were inoculated with macerated agar only

${ }^{f}$ Positive control plants were inoculated with a mixture of GWD isolates only and received no treatment with any of the products

*Treatments 1-7 were applied one week before inoculation with the pathogen and repeated one day before inoculation directly after wounding of the roots as described above. The plants were inoculated with the pathogen as described in Trial 1 the following day. One week after inoculation treatments 1-7 were repeated and thereafter applied weekly for six weeks. Treatment 8 was applied one day before inoculation with the pathogen after wounding of the roots and repeated 1 week later. 
Three rhizobacterial strains from the University of Pretoria's Plant Growth Promoting Rhizobacteria (PGPR) culture collection were included in Trials 2 and 3 . The strains were previously identified by sequencing the 16srRNA gene regions as: Paenibacillus alvei strain T29, Bacillus cereus strain S7 and Lysinibacillus sphaericus strain T19. In trial $3, B$. cereus S7 was replaced with $L$. sphaericus T19 due to the fact that some $B$. cereus strains are known to produce entero toxins hazardous to humans. Subsequently B.cereus S7 was tested for production of the diarrhoeal toxin by the National Health Laboratory Service, Parktown, South Africa, but the strain tested negative for the toxin. The bacteria were grown in nutrient broth (Biolab, Wadeville) at $25^{\circ} \mathrm{C}$ in a shake incubator for 48 hours. The broth cultures were used undiluted to treat the test plants by means of a drench treatment applied to the roots in the plant bags.

The experimental layout of Trial 3 was a randomized complete block design with 14 treatments randomly allocated within each of 3 replicate blocks. Each experimental unit consisted of 4 plants (total of 12 plants per treatment). The treatments are listed in Table 3. 
Table 3. Details of treatments evaluated for control of GWD in a shade house during Trial 3

\begin{tabular}{|c|c|c|c|c|}
\hline $\begin{array}{c}\text { Treatment } \\
\text { no* }^{*}\end{array}$ & Treatment & Active ingredient & Concentration & $\begin{array}{c}\text { Application method } \\
\text { and dosage }\end{array}$ \\
\hline \multicolumn{5}{|c|}{ Roots wounded } \\
\hline 1 & $\begin{array}{l}\text { Eco- }^{(B)}+ \\
\text { Rhizovital }\end{array}$ & $\begin{array}{c}\text { Trichoderma harzianum }\left(2 \times 10^{y} \text { spores/gram }\right)+ \\
\text { Bacillus amyloliquefaciens }\end{array}$ & $\begin{array}{c}\text { Eco-T } T^{(\Theta)}(250 \mathrm{~g} / \mathrm{ha} \text { or } 500 \mathrm{~g} / \mathrm{ha} \text { depending on } \\
\text { application date })+ \text { Rhizovita }^{(\Theta)}(500 \mathrm{ml} / \mathrm{ha})\end{array}$ & $\begin{array}{c}\text { Drench }(200 \mathrm{~mL} / \text { plant } \\
\text { bag })\end{array}$ \\
\hline 2 & $\begin{array}{c}\text { Eco- }^{(\Theta)}+ \\
\text { Rhizovital }^{(\circledast)}+ \\
\text { AgriSil }^{\text {TM }} \text { K50 }\end{array}$ & $\begin{array}{c}\text { Trichoderma harzianum }\left(2 \times 10^{9} \text { spores/gram }\right)+ \\
\text { Bacillus amyloliquefaciens } \\
+ \text { potassium silicate }^{\mathrm{b}}\end{array}$ & $\begin{array}{c}\text { Eco-T }^{\circledR a}(250 \mathrm{~g} / \text { ha or } 500 \mathrm{~g} / \text { ha depending on } \\
\text { application date })+ \text { Rhizovital }^{\circledR}(500 \mathrm{ml} / \mathrm{ha})+ \\
\text { AgriSil }^{\mathrm{TM}} @ 1 \mathrm{~mL} / \mathrm{L}\end{array}$ & $\begin{array}{l}\text { Drench }(200 \mathrm{~mL} / \text { plant } \\
\text { bag })\end{array}$ \\
\hline 3 & Breakdown-all & $\begin{array}{l}\text { Specific bacterial metabolites such as natural } \\
\text { enzymatic compounds - activates soil microflora }\end{array}$ & $5 \mathrm{~mL} / \mathrm{L}$ & $\begin{array}{l}\text { Drench }(200 \mathrm{~mL} / \text { plant } \\
\text { bag) }\end{array}$ \\
\hline 4 & UP-PGPR strains ${ }^{c}$ & Paenibacillus alvei T29 + Lysinibacillus & $\begin{array}{c}100 \mathrm{~mL}^{d} \text { of strain } \mathrm{T} 19+100 \mathrm{~mL}^{d} \text { of strain } \\
\text { T29 }\end{array}$ & Drench $(200 \mathrm{~mL} /$ plant \\
\hline 5 & $\begin{array}{l}\text { Microbial }^{e} \\
\text { Solutions }\end{array}$ & 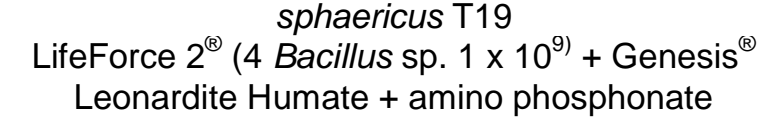 & $\begin{array}{l}2 \mathrm{~mL} \text { LifeForce } 2^{(\circledast)}, 8 \mathrm{~mL} \text { Humate, } 10 \mathrm{~mL} \\
\text { Superguard }^{(\circledast)} \text { per tree (in } 200 \mathrm{~mL} \text { water) }\end{array}$ & $\begin{array}{c}\text { bag }) \\
\text { Drench }(200 \mathrm{~mL} / \text { plant } \\
\text { bag })\end{array}$ \\
\hline 6 & Positive control & - & - & \\
\hline 7 & Negative control & - & - & \\
\hline \multicolumn{5}{|c|}{$\begin{array}{l}\text { Roots not } \\
\text { wounded }\end{array}$} \\
\hline 8 & $\begin{array}{r}\text { Eco-T }^{(\Theta)}+ \\
\text { Rhizovital }^{(\circledast)}\end{array}$ & $\begin{array}{c}\text { Trichoderma harzianum }\left(2 \times 10^{9} \text { spores/gram }\right)+ \\
\text { Bacillus amyloliquefaciens }\end{array}$ & $\begin{array}{c}\text { Eco-T }^{\circledast}(250-500 \mathrm{~g} / \text { ha depending on } \\
\left.\text { application time }{ }^{\mathrm{a}}\right)+ \text { Rhizovital }^{\Theta}(500 \mathrm{~mL} / \mathrm{ha})\end{array}$ & $\begin{array}{c}\text { Drench }(200 \mathrm{~mL} / \text { plant } \\
\text { bag })\end{array}$ \\
\hline 9 & $\begin{array}{c}\text { Eco-T }^{(\circledast)}+ \\
\text { Rhizovital }^{(\circledast)}+ \\
\text { AgriSil }^{\text {IM }} \text { K50 }\end{array}$ & $\begin{array}{c}\text { Trichoderma harzianum }\left(2 \times 10^{y} \text { spores/gram }\right)+ \\
\text { Bacillus amyloliquefaciens } \\
+ \text { potassium silicate }^{\mathrm{b}}\end{array}$ & $\begin{array}{c}\text { Eco- } T^{(\Theta)} 250-500 \mathrm{~g} / \text { ha depending on } \\
\text { application time } \mathrm{a}^{\mathrm{a}}+\text { Rhizovital }^{(\Theta} \\
(500 \mathrm{~mL} / \mathrm{ha})+ \\
\text { AgriSil }^{1 \mathrm{M}} @ 10 \mathrm{~mL} / \mathrm{L}\end{array}$ & $\begin{array}{l}\text { Drench }(200 \mathrm{~mL} / \mathrm{plant} \\
\mathrm{bag})\end{array}$ \\
\hline 10 & Breakdown-all & $\begin{array}{l}\text { Specific bacterial metabolites such as natural } \\
\text { enzymatic compounds - activates soil microflora }\end{array}$ & $5 \mathrm{ml} / \mathrm{L}$ & $\begin{array}{l}\text { Drench }(200 \mathrm{~mL} / \text { plant } \\
\text { bag })\end{array}$ \\
\hline 11 & UP-PGPR strains ${ }^{c}$ & Paenibacillus alvei T29 + Lysinibacillus & $\begin{array}{c}100 \mathrm{~mL}^{\mathrm{d}} \text { of strain } \mathrm{T} 19+100 \mathrm{~mL}^{\mathrm{d}} \text { of strain } \\
\text { T29 }\end{array}$ & Drench $(200 \mathrm{~mL} /$ plant \\
\hline 12 & $\begin{array}{l}\text { Microbial } \\
\text { Solutions }^{e}\end{array}$ & 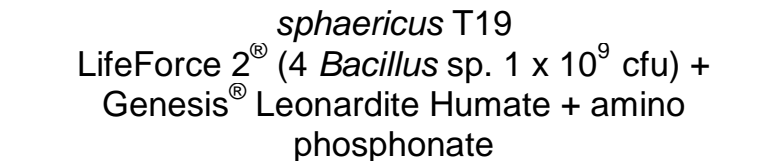 & $\begin{array}{l}2 \mathrm{~mL} \text { LifeForce } 2^{(\Theta)}, 8 \mathrm{~mL} \text { Humate, } 10 \mathrm{~mL} \\
\text { Superguard }^{(\Theta)} \text { per tree (in } 200 \mathrm{~mL} \text { water) }\end{array}$ & $\begin{array}{l}\text { bag }) \\
\text { Drench }(200 \mathrm{~mL} / \text { plant } \\
\text { bag })\end{array}$ \\
\hline 13 & Positive control $^{\dagger}$ & 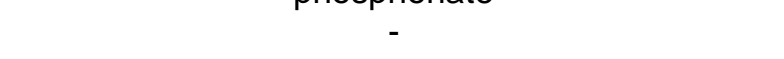 & - & \\
\hline
\end{tabular}


${ }^{a}$ Eco- $^{\circledR}{ }^{\circledR}(250 \mathrm{~g} / \mathrm{ha})$ for all application times except first application (February) and September application (500g/ha)

${ }^{b}$ Soluble silica liquid fortified with potassium

${ }^{c}$ Rhizobacterial strains from the University of Pretoria's PGPR culture collection.

${ }^{\mathrm{d}}$ Bacterial cells in broth culture.

e ${\text { LifeForce } 2^{\circledR}+\text { Humate + Superguard }}^{\circledR}$

${ }^{\dagger}$ Negative control plants were inoculated with macerated agar only

${ }^{g}$ Positive control plants were inoculated with a mixture of 3 GWD isolates only and received no further treatments

* All products were applied two weeks before inoculation with the pathogen in February. In treatments 1-7 the applications were repeated two weeks later after wounding of the roots as described for Trial 2 and inoculated with the pathogen as described above, after 18h. In treatments 8-13 application times were the same as for treatments 1-7 but without wounding of the roots. Plants were inoculated with the pathogen as described for Trial 1 and 2 . All treatments were repeated a month and two months after inoculation and thereafter at 2 monthly intervals until August. From September onward treatments were repeated monthly up to December as this time coincides with the critical infection period in the orchard. 
In Trial 1 plants were evaluated for guava wilt disease two months after inoculation with the pathogen using a scale of $1-5$ where $1=4$ or less leaves turned purple, $2=5$ or more leaves turned purple, $3=$ quarter of plant wilted $(>8$ leaves turned purple), $4=$ half of plant wilted and $5=$ dead plants. Results are expressed in terms of an index according to Wheeler (1969) where disease index $=($ Sum of all numerical ratings/ total number of plants $) \times(100 /$ Maximum disease category). In Trial 2 and 3 data were recorded as number of dead plants at termination of the trials, 24 and 12 months after pathogen inoculation, respectively.

The data of each trial were subjected to an appropriate analysis of variance. The Shapiro-Wilk's test was performed on the standardized residuals to test for deviations from normality (Shapiro and Wilk, 1965). In cases where significant deviation from normality was found and it was due to skewness, outliers were removed until it was normalised or symmetrically distributed (Glass et al. 1972). Student's t-LSD (Least significant difference) was calculated at a $5 \%$ significance level to compare means of significant source effects. All the above data analysis was performed with SAS version 9.3 statistical software (SAS 1999).

\section{Results and discussion}

Trial 1. The results of Trial 1 are presented in Fig. 1. None of the treatments caused a significant reduction in GWD. To the contrary, all treatments seemed to aggravate the disease. However, statistically significant increases in disease indices compared to the positive control were recorded only in the two Trichoderma (Eco-T ${ }^{\circledast}$ and Tricho plus ${ }^{\circledR}$ ), Indar ${ }^{\circledast} 500 \mathrm{EW}$, A-team, Bendazid ${ }^{\boxplus}$ and Amistar ${ }^{\circledast}$ treatments. This surprising result might have been due to either a phytotoxic stress-related effect on the plants or suppression of competitive (beneficial) organisms in the rhizosphere. Although the lowest disease indices were recorded with the Bion ${ }^{\circledR}$, DPress ${ }^{\circledR}$ and Rally ${ }^{\circledR}$ treatments respectively, they all resulted in a higher disease index than the untreated pathogen-inoculated control. The two Trichoderma treatments and Amistar gave the highest disease indices. None of the uninoculated (negative) control plants developed any GWD symptoms. In Taiwan carbendazim, captafol and thiabendazole proved effective against $N$. psidii in vitro (laboratory experiments), but failed in vivo (Leu et al. 1979). In SA tebuconazole, propiconazole, prochloraz, triforine and carbendazim + flusilazole were effective in in vitro evaluations, against $N$. psidii, but failed in further field trials (Joubert \& Frean 1993). In Malaysia a reduction in guava wilt disease incidence caused by $N$. psidii could be obtained by eliminating the use of chicken manure which burned the roots, predisposing them to infection, and by adding arbuscular mycorrhizae to the soil before planting (C.T. Ho, Golden Hope Plantations Berhad, Malaysia, pers.I comm.,1997).

In the current study our approach was to evaluate chemical fungicides that are known to induce resistance in the plant (plant activators such as AcibenzolarS-methyl) as well as curative systemic fungicides, regardless of their in vitro 


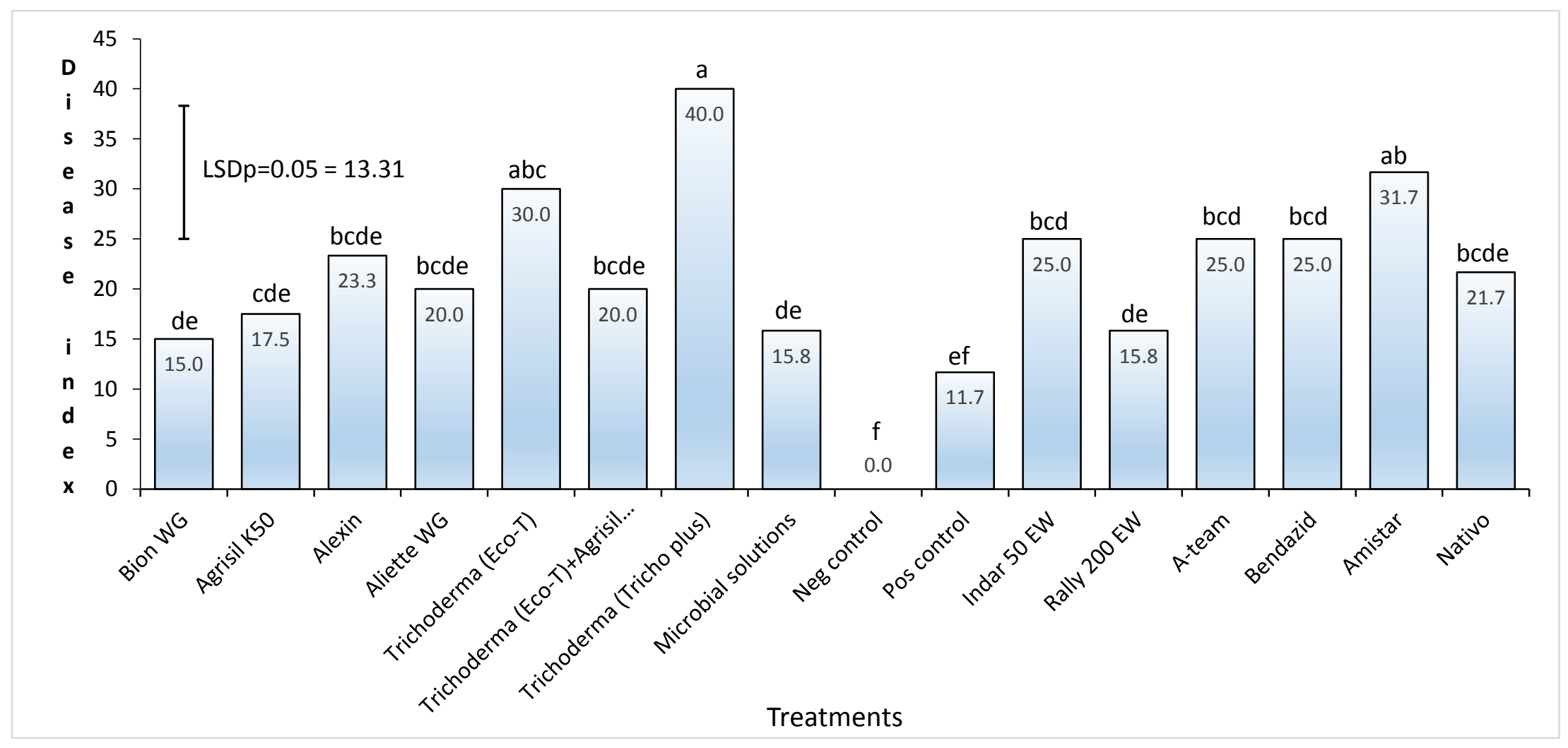

Figure 1. The effect of various chemical and biological treatments on the incidence of guava wilt disease in a shade house trial conducted over a period of 2 months (trial 1). Plants were evaluated using a scale of $1-5$ where $1=4$ or less leaves turned purple, $2=5$ or more leaves turned purple, $3=$ quarter of plant wilted $(>8$ leaves turned purple, $4=$ half of plant wilted and $5=$ dead plants. The disease index was calculated as (sum of all numerical ratings/total number of plants) $x(100 /$ maximum disease category $)$. 
activity against $N$. psidii, because most plant activators do not show direct antifungal activity.

Trial 2: The best control of GWD was achieved with the UP - PGPR strains (treatment 6) resulting in only 2 plants out of 15 dead 24 months after inoculation, compared with 10 out of 15 plants $(66.6 \%)$ dead in the pathogen-inoculated (positive) control (Fig. 2). This represents $53.4 \%$ disease control by the rhizobacterial strains (Bacillus cereus strain S7 and Paenibacillus alvei strain T29). This treatment was however not significantly different from the treatments with Bion and DPress that resulted in 5 and 6 plants dead respectively (compared to 10 out of 15 in the positive control), but these results did not differ significantly from the positive control. It was also noticeable that the plants receiving the UP-PGPR strains had much greener, healthier leaves than any of the other treatments and the stem diameter of these plants was also significantly greater (data not shown), implying that this treatment had some plant growthenhancing effects apart from disease suppression. None of the uninoculated (negative) control plants developed any GWD symptoms.

Trial 3. In trial 3, the only treatment that significantly reduced GWD incidence in wounded plants was the bacterial drench with the UP-PGPR strains Paenibacillus alvei T29 + Lysinibacillus sphaericus T19 (Fig. 3) resulting in 4 out of a total of 12 plants dead (33.3\%) in comparison with 10 plants out of a total of 12 plants dead (83.3\%) in the wounded (positive) control plants. This represents $50 \%$ disease control by the Rhizobacterial strains (Paenibacillus alvei T29 + Lysinibacillus sphaericus T19) in the wounded plants

Amongst the unwounded plants only 3 of the pathogen-inoculated (positive) control plants died out of a total of 12 plants (i.e. 25\%), in comparison with 10 plants dead amongst the wounded (positive) controls out of a total of 12 plants (i.e. 83.3\%) over the 12-month period. This clearly demonstrates that wounding dramatically enhances disease development. This pattern was similar to findings by Hong et. al (2015) where damage to roots caused by typhoons or weed control resulted in aggravation of GWD caused by N. psidii in Taiwan.

Amongst the unwounded plants, best disease suppression was achieved with Breakdown-all, although not significantly better than the positive control or any of the other treatments.

Even though in Trial $3 B$. cereus strain S7 was replaced with $L$. sphaericus T19 and the application intervals were different than those in trial 2, the level of disease suppression obtained were very similar in the two trials (53\% in trial 2 vs $50 \%$ in trial 3 ).

\section{Conclusions}

This is to our knowledge the first report of control of GWD caused by N. psidii by means of bacterial antagonists. Plant growth-promoting rhizobacteria are widely reported as effective biocontrol agents in a wide range of crops (Lucy et al. 2004; Zahir et al. 2004). Biocontrol mechanisms of PGPR include amongst others 


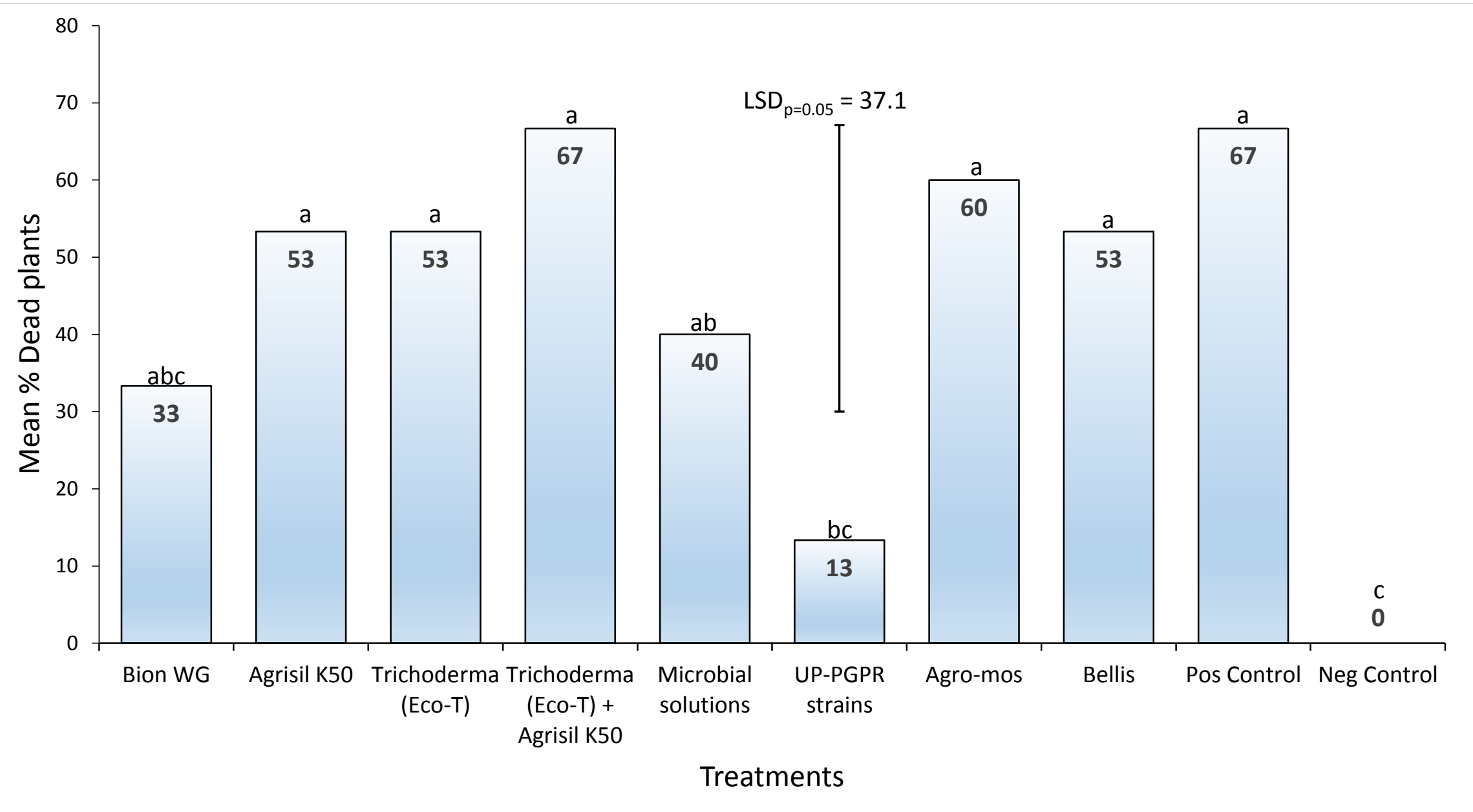

Figure 2. The effect of various chemical and biological treatments on the incidence of guava wilt disease, 24 months after inoculation with Nalanthamala psidii in a glasshouse trial (trial 2). Data were subjected to an appropriate analysis of variance. Student's t-LSD was calculated at a $5 \%$ significance level to compare means of significant source effects. 


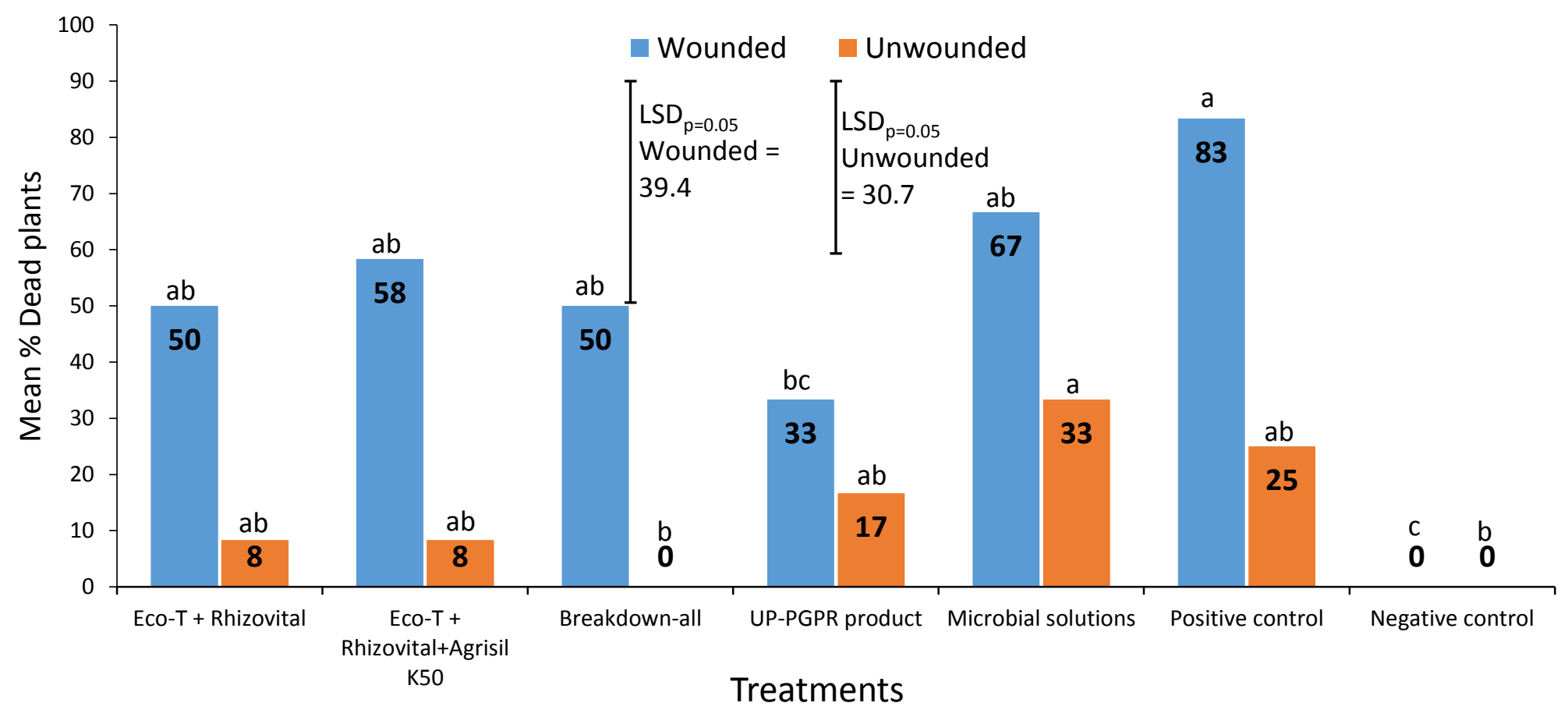

Figure 3. The effect of various biological treatments on the incidence of guava wilt disease, 12 months after inoculation with Nalanthamala psidii in a shade house trial (trial 3). Data were subjected to an appropriate analysis of variance. Student's t-LSD was calculated at a $5 \%$ significance level to compare means of significant source effects. 
antibiosis (eg. by production of antifungal metabolites), parasitization, induction of systemic resistance, hydrogen cyanide production $(\mathrm{HCN})$, sequestering of iron through production of siderophores and competition for nutrients and niches (Bloemberg and Lugtenberg 2001, Lugtenberg \& Kamilova, 2009). The three rhizobacterial strains used in the current study (Bacillus cereus strain S7, Paenibacillus alvei T29 and Lysinibacillus sphaericus T19) have previously shown antibiosis activity in dual culture tests against multiple fungal species including Fusarium oxysporum, Rhizoctonia solani and Verticillium dahliae (N. Labuschagne unpublished). It is therefore probable that these strains exerted antagonism against the GWD pathogen in the current study, although the exact mechanism of biocontrol remains to be elucidated. It must however be emphasised that the trials in this study were conducted on nursery plants in a shadehouse and glasshouse where the bacterial strains could be applied to the entire root system of the plants. In light of the fact that the GWD pathogen spreads systemically through the vascular system of the tree (Lim \& Manicom, 2003) it can be expected that it will be more difficult to obtain disease control under field conditions.

Future research will include field evaluation of the UP-PGPR strains. Commercialisation of the strains is being pursued by the University of Pretoria in collaboration with private companies.

\section{References}

Bloemberg GV, Lugtenberg BJJ. 2001. Molecular basis of plant growth promotion and biocontrol by rhizobacteria. Current Opinion in Plant Biology 4:343350.

Glass GV, Peckham PD, Sanders JR. 1972. Consequences of failure to meet assumptions underlying the fixed effects analyses of variance and covariance. Review of Educational Research 42(3): 237-288.

Grech NM. 1985. First report of guava death syndrome caused by Septofusidium sp. In South Africa. Plant Disease 69: 726.

Grech NM. 1986. Study visit on guava wilting disease in the Republic of China. CSFRI Report, Nelspruit.

Grech NM. 1990. Guava wilting disease in Levubu. CSFRI Information Bulletin 218:8.

Hong CF, Hsiesh HY, Chen KS, Huang HC. 2015. Importance of root infection in guava wilt disease caused by Nalanthamala psidii. Plant Pathology 64:450-455.

Joubert MH, Frean RT. 1993. An in vitro evaluation of fungicides against wilt. Information Bulletin-Institute for Tropical and Subtropical Crops 246:3.

Leu LS, Kao CW, Wang CC, Liang WJ, Hsieh SPY. 1979. Myxosporium wilt of guava and its control. Plant Disease Reporter 63: 1075-1077.

Lim TK, Manicom BQ. 2003. Diseases of guava. In: Ploetz RC (ed.), Diseases of Tropical Fruit Crops. CABI Publishing, Wallingford, UK. pp 275-287.

Lucy M, Reed E, Glick BR. 2004. Applications of free living plant growthpromoting rhizobacteria. Antonie Leeuwenhoek 86:1-25. 
Lugtenberg B, Kamilova F. 2009. Plant Growth Promoting Rhizobacteria. Microbiology 63: 541-556.

Misra AK, Pandey BK. 1999. Pathogenicity and evaluation of fungicides against guava wilt pathogens. Journal of Mycology and Plant Pathology 29: 274275.

SAS Institute, Inc. (1999), SAS/STAT User's Guide, Version 9, $1^{\text {st }}$ printing, Volume 2. SAS Institute Inc, SAS Campus Drive, Cary, North Carolina 27513.

Schoeman MH. 1995. Vrystelling van verwelksiektebestande koejawelonderstamme. LNR-ITSG Inligtingsbulletin 278: 5-6.

Schoeman MH, Benade E, Wingfield M.J. 1997. The symptoms and cause of Guava Wilt in South Africa. Journal of Phytopathology 145: 37-41.

Schoeman MH. 2011. The current status of Guava Wilt Disease in South Africa. SA Fruit Journal, Aug/Sept 2011, 46-49.

Schoeman MH, Labuschagne N. 2014. Preliminary evaluation of guava selections for guava wilt disease resistance in South Africa. South African Journal of Plant and Soil 2014:1-4.

Schroers H-J, Geldenhuis MM, Wingfield MJ, Schoeman MH, Yen YF, Shen WC, Wingfield BD. 2005. Classification of the guava wilt fungus Myxosporium psidii, the palm pathogen Gliocladium vermoesenii and the persimmon wilt fungus Acremonium diospyri in Nalanthamala. Mycologia 97(2): 375-95.

Shapiro SS, Wilk MB. 1965. An Analysis of Variance Test for Normality (complete samples). Biometrika 52: 591-611.

Vos JE, Schoeman MH, Berjak P, Watt MP, Toerien AJ. 2000. In vitro selection and commercial release of Guava Wilt resistant rootstocks. Acta Horticulture 513:69-79.

Wheeler BEJ. 1969. An introduction to plant diseases. New York: John Wiley \& Sons Ltd.

Zahir ZA, Arshad M, William T, Frankenberger WT. Jr. 2004. Plant growth promoting rhizobacteria: applications and perspectives in agriculture. Advance in Agronomy 81:97-168 